\title{
The probability of potentially useful work days during the year in Londrina
}

\section{Probabilidade de dias potencialmente úteis de trabalho durante o ano em Londrina}

\author{
Letícia Trindade Ataíde ${ }^{1 *}$; Paulo Henrique Caramori²; Wilian da Silva Ricce ${ }^{3}$; \\ Danilo Augusto Bambini Silva ${ }^{4}$; José Roberto Pinto de Souza ${ }^{5}$
}

\begin{abstract}
The probabilities associated with the number of days suitable for working outdoors and for working with machinery in the field were estimated for the municipality of Londrina, state of Parana, Brazil. Days with less than $10 \mathrm{~mm}$ of precipitation were considered suitable for outdoor operations. The number of days per month and the number of ten-day periods satisfying this condition were modeled with a negative binomial distribution, and the probabilities were estimated at different levels. The days suitable for working with machinery in the field were specified as those days for which the values of water storage in the soil were at or below $90 \%$ of the available water capacity in the upper $30 \mathrm{~cm}$ of the soil and for which the precipitation was less than $5 \mathrm{~mm}$. A first-order Markov chain was used to estimate the conditional probabilities of favorable days for working with machinery in the field. The results indicated that the best time to work outdoors in Londrina extends from April through September, with the most favorable period occurring between late July and early September. The highest probabilities of favorable days for working in the field occur during April and from June through August. The probabilities of two consecutive days favorable for working with machinery in the field are highest between June and August. These probabilities allow the determination of the needs for the performance of tasks involving mechanized equipment.
\end{abstract}

Key words: Negative binomial distribution, Markov Chain, conditional probability, outside works, agriculture trafficability

\section{Resumo}

Foram estimadas as probabilidades de dias úteis de trabalho em locais descobertos e a trafegabilidade de maquinários no campo, para o município de Londrina-PR. Dias com precipitação igual ou superior a $10 \mathrm{~mm}$ foram considerados inadequados para operações a céu descoberto. O número de dias mensais e decendiais que satisfazem essa condição foram ajustados à distribuição binomial negativa e foram estimadas as probabilidades em diferentes níveis. Os dias favoráveis ao trabalho com máquinas no campo foram estabelecidos como aqueles em que os valores de armazenamento de água no solo eram iguais ou inferiores a $90 \%$ da capacidade de água disponível na camada superficial de $30 \mathrm{~cm}$ do solo e a menor que $5 \mathrm{~mm}$. O método da cadeia de Markov de primeira ordem foi utilizado para estimar as

1 Agronomist, Doctor Student in Agronomy, Graduate studies Dept., CCA, University of Londrina, UEL, Rod. Celso Garcia Cid, Km 380, CEP: 86051-990, Londrina, PR. E-mail: leticia_trindade@yahoo.com.br

2 Agronomist, PhD, Research Scientist at Instituto Agronômico do Paraná, IAPAR, Rod. Celso Garcia Cid, Km 375, CEP: 86047902, Londrina, PR. E-mail: caramori@iapar.br

3 Agronomist, Doctor in Agronomy, Researcher at Agroconsult Ltda, IAPAR, Londrina, PR. E-mail: wilianricce@gmail.com

4 Expert in Computer Science at Agroconsult Ltda, IAPAR, Londrina, PR. E-mail: daniloaugusto@gmail.com

5 Agronomist, Prof. Dr. at the Agronomy Dept ${ }^{\circ}$ of University of Londrina, UEL, Londrina, PR. E-mail: jose@uel.br Author for corespondence 
probabilidades condicionais de dias favoráveis ao trabalho com máquinas. Os resultados indicam que o melhor período para realização de obras em ambiente externo em Londrina se estende de abril a setembro, com ótimo entre final de julho e início de setembro. As maiores probabilidades de um dia ser favorável à execução de práticas mecanizadas no campo compreendem o mês de abril e os meses de junho a agosto, e as probabilidades de dois dias seguidos favoráveis ao tráfego de maquinários no campo apresentam ótimo entre os meses de junho e agosto. Essas probabilidades possibilitam determinar as necessidades de máquinas para execução das práticas mecanizadas.

Palavras-chave: Distribuição binomial negativa, cadeia de Markov, probabilidade condicional, obras em ambiente externo, trafegabilidade agrícola

\section{Introduction}

The climatic conditions of a place or region will determine the number of days available during the year to perform outdoor work, such as the construction and repair of houses, buildings, roads and dams and the operation of machinery on agricultural soils. Prolonged and intense rainfall events cause the greatest difficulties for outdoor operations, contributing to cost increases associated with manual labor and delays in schedules (SILVA et al., 2007). The actual number of days of work in the State of São Paulo during the summer is approximately $50 \%$ lower than in winter, with an average interruption of activities of $15 \%$ due to weather conditions (RICARDO, CATALANI, 1990).

The displacement of work crews and the exposure of materials in open places are factors that raise costs and delay projects in general. In these cases, two situations must be addressed by decision makers. These situations are based on the weather (forecasts at short intervals, from few hours to one week) and on the climate, indicated by the mean rainfall for at least 30 years, as recommended by the World Meteorological Organization. The weather forecast can direct the initiation of tasks such as road rehabilitation, the renovation and installation of roofs, external finishing and the transport of workers. However, project planning activities must be based on the climate of the region, with priority allocated to outdoor activities when rainfall is less probable (BAZZANO; ELTZ; CASSOL, 2007).

In agriculture, the feasibility of operation of the machinery, from soil preparation to harvest, depends on the dynamics of water in the surface layers of soil as an indicator that can assist in decision making (FERNANDES; SOUZA; VITORIA, 2000). The moisture in the surface layers of the soil affects the properties of bearing capacity, shear force, friction and adhesion, determining its ability to bear traffic (CASTRO NETO, 2001). Because soil moisture influences the conditions under which motorized machinery (e.g., tractors) can be operated, planning based on the distribution and amount of rainfall can produce a count of the number of days favorable for field work and can therefore reduce the manpower and time expenses required to conduct such activities (ASSIS et al., 1989). Achieving greater use of the days on which agricultural machines can be used is of utmost importance because tractors can travel only with difficulty if the soil moisture is excessive. The excess moisture causes soil compaction, and the soil collects on the working surfaces of the machinery. This situation results in unsatisfactory yields (ASSIS et al., 1989).

According to Assis et al. (1989), the statistical dependence of a given day's weather on the previous day's weather justifies the use of Markov chain methods to obtain forecasts of the number of days suitable for working in the field. Assis et al. (1989) and Fernandes, Souza and Vitoria (2000) considered that the conditions for field work would be favorable on a given day if the available soil water on that day was less than or equal to $90 \%$ in the first $15 \mathrm{~cm}$ of the profile. A day with $5 \mathrm{~mm}$ or more rainfall (equivalent to the average daily potential evapotranspiration) was considered an unfavorable day for field work regardless of the 
amount of available soil water. Any day that showed precipitation of $10 \mathrm{~mm}$ or more on the previous day was also classified as an unfavorable day for field operations. Selirio and Brown (1972) concluded that cultivation is possible if the soil water content is equal to or less than $90 \%$ of the capacity of the field depth of $12 \mathrm{~cm}$, irrespective of the water content in the deeper layers.

According to Peloia and Milan (2010) and Salvador et al. (2010), it is of fundamental importance under the conditions of intensive cultural practices and of farms occupying large areas to program operations with machines in the field in a rational manner for the efficient use of agricultural machinery and hand labor. Castro Neto (2001) observed that if a long series of meteorological data is available, it is important to conduct climatological studies by calculating the water balance in the soil and classifying the days as fit or unfit for various mechanized activities, types of soil and agricultural activities of interest.

The objectives of this study were to estimate the probabilities of potentially useful days for work in open places and for the trafficability of the soil for machinery in the field in the municipality of Londrina, northern Parana State, Brazil.

\section{Materials and Methods}

We used daily rainfall data for 1961-2010 from the meteorological stations of the Agronomic Institute of Paraná (IAPAR) and the National Institute of Meteorology (INMET) for the city of Londrina $\left(23^{\circ} 22^{\prime} \mathrm{S}\right.$ latitude, $51^{\circ} 10^{\prime} \mathrm{W}$ longitude, $585 \mathrm{~m}$ altitude). The local soil in the region where IAPAR is located is classified as Oxisol clayey (EMBRAPA, 2006). Note, however, that the local soils in the city of Londrina include other types of soils in addition to those cited in this study.

\section{Days suitable for working outdoors}

Initially, we recorded the days in the data series on which the rainfall was less than $10 \mathrm{~mm}$. Days with greater amounts of rainfall were considered to be days on which tasks requiring clear skies could not be performed.

As the variance $\left(\mathrm{s}^{2}\right)$ of the data was higher than the average $(\bar{X})$, we used the negative binomial distribution model (ASSIS; ARRUDA; PEREIRA, 1996) to analyze monthly and ten-day periods by determining the theoretical frequency distribution of the number of days during the year on which the rainfall was greater than or equal to $10 \mathrm{~mm}$. This analysis was based on the 50-year data series.

According to Assis, Arruda and Pereira (1996), the probability function for the negative binomial distribution takes the following form:

$$
p(X)=\frac{\Gamma(X+K)}{\Gamma(X+1) \Gamma(K)} \frac{P^{X}}{(1+P)^{K+X}}
$$

The parameters $\mathrm{P}$ and $\mathrm{K}$ are estimated as follows:

$$
P=\frac{1}{\bar{X}}\left(s^{2}-\bar{X}\right), K=\frac{\bar{X}^{2}}{s^{2}-\bar{X}},
$$

where

$\mathbf{s}^{2}=$ variance of sample data

$\bar{X}=$ sample mean.

A nonparametric Kolmogorov-Smirnov (KS) test was used to evaluate the fit of the negative binomial distribution to the observations. This test can be used to evaluate the null hypothesis $\left(\mathbf{H}_{\mathbf{0}}\right)$ that the values of a time series originate from a population with a pre-established theoretical distribution (ASSIS; ARRUDA; PEREIRA, 1996; BLAIN; BRUNINI, 2007). The test was defined as follows:

$$
\begin{gathered}
\operatorname{Dmax}=\operatorname{Max}\left|F^{\prime}(\mathbf{x})-\mathbf{F}(\mathbf{x})\right| \\
\mathbf{F}(\mathbf{x})=\mathbf{F a} /(\mathbf{N}+\mathbf{1}),
\end{gathered}
$$


where

Max $=$ largest absolute value among the frequency classes defined for the test;

Dmax $=$ difference value calculated for the Kolmogorov-Smirnov test;

$\mathbf{F}^{\prime}(\mathbf{x})=$ theoretical distribution function;

$\mathbf{F}(\mathbf{x})=$ empirical distribution function (derived from the sample data);

$\mathbf{F a}=$ cumulative frequency of each class;

$\mathbf{N}=$ number of classes of default values .

The null hypothesis $\left(\mathbf{H}_{\mathbf{0}}\right)$ that the sample data represent a negative binomial distribution is rejected if the calculated value of Dmax is greater than or equal to the tabulated value (critical value) corresponding to the specified significance level ( $5 \%$ for this study). The KS test was applied to the monthly and decennial data for all months of the year. Adjusted polynomial functions were used to fit the cumulative probabilities, and values were obtained from these functions to describe the number of days on which the rainfall was greater than or equal to $10 \mathrm{~mm}$ at probability levels of 10 , 25, 50, 75 and 90\% (ASSIS; ARRUDA; PEREIRA, 1996).

Days allowing the operation of machinery in the field

To calculate the number of days of work in the field, we used the sequential water balance method of Thornthwaite and Mather (1955) with the daily potential evapotranspiration estimated by the Penman-Monteith method. We used a spreadsheet developed for this purpose and available at IAPAR. According to Faria and Caramori(1986), the available water in the soil is approximately $10 \%$ by volume. A depth of $30 \mathrm{~cm}$ corresponds to the soil layer used for cultivation. This layer includes approximately $80 \%$ of the root system of most annual species. Under these conditions, the value of the yield of available water (CAD) in the soil is $30 \mathrm{~mm}$.
In the model of Thornthwaite and Mather (1955), the storage of water in the profile (ARM) is given by the following negative exponential function:

$$
\mathbf{A R M}=\mathbf{C A D} \mathrm{e}^{-|\mathrm{NAc} / \mathrm{CAD}|},
$$

where

$\mathbf{N A c}=$ cumulative negative when $\Sigma=(\mathrm{P}-\mathrm{ETP})<0$

$$
\text { NAc }=\text { CAD Ln ARM/CAD . }
$$

The days on which the precipitation was less than $5 \mathrm{~mm}$ and / or the value of the ARM was less than $90 \%$ of the CAD in the 30 -cm surface layer of the soil were considered favorable for work in the field (ASSIS et al., 1989). Otherwise, the days were considered unfit for traffic involving machinery because such traffic would increase the occurrence of soil compaction in the presence of excessive moisture. Under these conditions, the performance and wear of the tractor are also affected (NAGAOKA et al., 2003; ARAUJO-JUNIOR et al., 2011).

Because two consecutive days with rain reflect the persistence of the previous day's weather, the values of the meteorological parameters for the previous day were incorporated in the selection of favorable days to work. Therefore, a first-order Markov chain was used to estimate the conditional probabilities of occurrence of days suitable for work. These estimates were based on the methodology adopted by Assis et al. (1989):

$\mathbf{P}$ (F) $=$ number of years in which favorable conditions occurred on the first day / total number of years;

$\mathbf{P}(\mathrm{D})=\mathbf{1 . 0}-\mathbf{P}(\mathbf{F})$;

$\mathbf{P}(\mathbf{F} \mid \mathbf{F})=$ number of days with favorable conditions on both the first and second days / number of years in which favorable conditions occurred on the first day;

$$
\begin{aligned}
& \mathbf{P}(\mathbf{D} \mid \mathbf{F})=\mathbf{1 . 0}-\mathbf{P}(\mathbf{F} \mid \mathrm{F}) \\
& \mathbf{P}(\mathbf{F} \mid \mathbf{D})=[\mathbf{P}(\mathbf{F}) * \mathbf{P}(\mathbf{D} \mid \mathbf{F})] / \mathbf{P}(\mathbf{D}) ; \\
& \mathbf{P}(\mathbf{D} \mid \mathbf{D})=\mathbf{1 . 0}-\mathbf{P}(\mathbf{F} \mid \mathbf{D}),
\end{aligned}
$$

Where: 
$\mathbf{P}(\mathbf{F})=$ probability of a favorable day;

$\mathbf{P}(\mathbf{D})=$ probability of one unfavorable day;

$\mathbf{P}(\mathbf{D} \mid \mathbf{F})=$ probability that a day is unfavorable if the previous day was favorable;

$\mathbf{P}(\mathbf{F} \mid \mathbf{D})=$ probability that a day is favorable if the previous day was unfavorable;

P (D | D) = probability that a day is unfavorable if the previous day was unfavorable;

$\mathbf{P}(\mathbf{F} \mid \mathbf{F})=$ probability that a day is favorable if the previous day was favorable.

\section{Results and Discussion}

Figure 1 shows the frequency of occurrence (expressed as a percentage) of rainy days in Londrina, PR. The driest period of the year occurred from April to September, with an optimum between the third ten days of July and the first ten days of September. This period is ideal for the harvesting and drying of grains and for activities involving the performance of services in the external environment.

All of the monthly and decennial frequency distributions of the days on which the rainfall was greater than or equal to $10 \mathrm{~mm} \mathrm{day}^{-1}$ in Londrina were well described by negative binomial probability distributions. The critical value of the KS statistic was $<0.1937$ (Table 1). The theoretical distribution appears to fit the empirical distribution throughout the period of analysis. This result shows that the parameters of the negative binomial probability distribution can be used to represent the trend of the series of monthly and decennial rainfall equal to or greater than $10 \mathrm{~mm}_{\text {day }}{ }^{-1}$ in Londrina to model the sequences of dry days suitable for outdoor work (Table 1).

Figure 1. Frequency of ten-day periods with rainfall equal or higher than $10 \mathrm{~mm}^{\text {day }}{ }^{-1}$ in Londrina, PR.

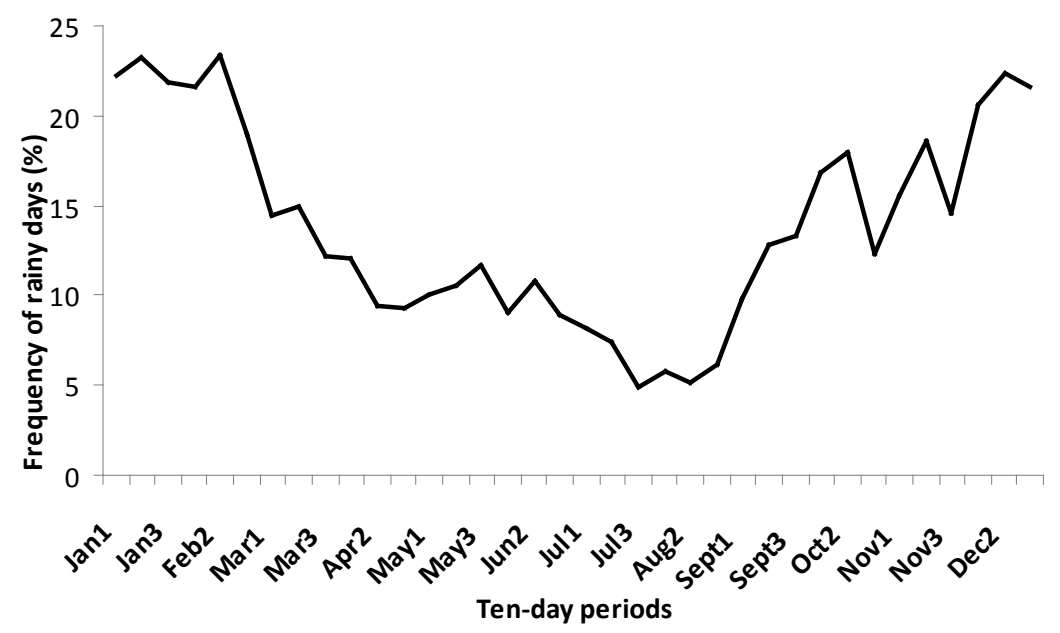

Source: Elaboration of the authors. 
Table 1. Adjustment of the series of rainfall values greater than or equal to $10 \mathrm{~mm}^{-1} \mathrm{y}^{-1}$ in Londrina to the negative binomial distribution for the months of the year and periods of ten days by the Kolmogorov - Smirnov test (calculated value of the goodness-of-fit test). The critical value at the 5\% significance level is 0.1937 .

\begin{tabular}{ccccc}
\hline Month & Monthly & $1^{\text {st }} 10$ days & $2^{\text {nd }} 10$ days & $3^{\text {rd }} 10$ days \\
\hline January & 0.0654 & 0.0442 & 0.0577 & 0.0542 \\
February & 0.0526 & 0.0398 & 0.0364 & 0.0674 \\
March & 0.0549 & 0.0643 & 0.0263 & 0.0604 \\
April & 0.0239 & 0.0465 & 0.0518 & 0.0757 \\
May & 0.0721 & 0.0402 & 0.0544 & 0.0410 \\
June & 0.0587 & 0.0313 & 0.0436 & 0.0518 \\
July & 0.0330 & 0.1100 & 0.0348 & 0.0300 \\
August & 0.0422 & 0.0430 & 0.0354 & 0.0544 \\
September & 0.0751 & 0.1043 & 0.0600 & 0.0584 \\
October & 0.0723 & 0.0464 & 0.0636 & 0.0476 \\
November & 0.0298 & 0.0244 & 0.0508 & 0.0513 \\
December & 0.0519 & 0.0418 & 0.0549 & 0.0856 \\
\hline
\end{tabular}

Source: Elaboration of the authors.

The negative binomial distribution has also been successfully used to estimate the number of days during the year when the rainfall exceeds $50 \mathrm{~mm}$ in Pelotas (ASSIS; ARRUDA; PEREIRA, 1996) and by Massignam and Dittrich (1998) to estimate the average number and monthly probability of occurrence of frost in the State of Santa Catarina.

Buriol et al. (1998) investigated the probability of occurrence of the minimum air temperature harmful to the pollination of rice flowers and found that the negative binomial distribution did not fit data series of air temperatures $\leq 13^{\circ} \mathrm{C}, 15^{\circ} \mathrm{C}$ and $17^{\circ} \mathrm{C}$. According to the authors, a cold air mass located over the region will remain for a day or more, producing a group of days with low temperatures.

A set of fourth-degree polynomial functions was used to represent the cumulative distributions of the occurrence of precipitation greater than or equal to 10 $\mathrm{mm}$ per day for periods of ten days each month. The correlation coefficients calculated for this analysis were near 1.0. Table 2 shows the number of days in the month with precipitation greater than or equal to $10 \mathrm{~mm}$ for probability levels of 10, 25, 50, 75 and $90 \%$. These values were extracted from the fitted curves specified by the polynomial functions for the city of Londrina. These levels refer to a specific probability of occurrence of a minimum number of days on which the rainfall would be unlikely to prevent the performance of outdoor tasks.

For example, for the month of January, the probability of the occurrence of at least 5.85 days on which the precipitation is less than $10 \mathrm{~mm}$ was $50 \%$. This probability indicates that the number of days of impairment is expected to exceed this value in two out of every four years. The $75 \%$ probability indicates that the number of days in January with rainfall less than $10 \mathrm{~mm}$ is not less than 3.85 days in one out of every four years. These data are useful if it is necessary to determine the month in which it is most probable that the work environment will be unsuitable based on a given rainfall value. The same reasoning is used to interpret Table 3.

In developing agricultural projects, the recommended level is a $75 \%$ probability of rainfall. A fixed probability value is used because the use of average values may cause the undersizing of projects (BERNARDO; MONTOVANI; SOARES, 2005; MURTA et al., 2005). This probability level can be used to calculate the duration of operations in environments in which the opportunities for performing necessary work depend on the weather conditions. 
Table 3 shows the number of days with at probability levels of 10, 25, 50, 75 and $90 \%$ for precipitation not less than $10 \mathrm{~mm}$ in a ten-day period the city of Londrina.

Table 2. Days with rainfall greater than or equal to $10 \mathrm{~mm}$ estimated from the negative binomial distribution for monthly periods from January to December in Londrina, PR, with different probability levels.

\begin{tabular}{cccccc}
\hline \multirow{2}{*}{ Month } & \multicolumn{5}{c}{ Probabilities (\%) } \\
\cline { 2 - 6 } & 10 & 25 & 50 & 75 & 90 \\
\hline January & 10.35 & 8.15 & 5.85 & 3.85 & 2.40 \\
February & 8.57 & 6.80 & 4.83 & 3.00 & 1.65 \\
March & 6.70 & 5.05 & 2.99 & 1.40 & 0.40 \\
April & 5.00 & 3.45 & 1.85 & 0.72 & 0.15 \\
May & 5.80 & 3.70 & 1.78 & 0.41 & 0.00 \\
June & 5.40 & 3.40 & 1.50 & 0.15 & 0.00 \\
July & 3.90 & 2.30 & 0.80 & 0.00 & 0.00 \\
August & 3.20 & 1.75 & 0.40 & 0.00 & 0.00 \\
September & 5.81 & 4.25 & 2.45 & 1.02 & 0.29 \\
October & 6.80 & 5.45 & 3.78 & 2.20 & 1.00 \\
November & 7.40 & 5.80 & 3.85 & 2.10 & 0.80 \\
December & 10.05 & 7.76 & 5.42 & 3.40 & 1.90 \\
\hline
\end{tabular}

Source: Elaboration of the authors.

Table 3. Days with rainfall greater than or equal to $10 \mathrm{~mm}$ estimated from the negative binomial distribution for 10day periods from January to December in Londrina, PR, with different probability levels.

\begin{tabular}{ccccccc}
\hline \multirow{2}{*}{ Periods } & \multirow{2}{*}{ 10-day periods } & \multicolumn{5}{c}{ Probabilities (\%) } \\
\cline { 3 - 6 } & & 10 & 25 & 50 & 75 & 90 \\
\hline $11-10 / 01$ & Jan 1 & 4.30 & 3.19 & 2.00 & 1.00 & 0.40 \\
$11-20 / 01$ & Jan 2 & 4.70 & 3.35 & 2.00 & 0.95 & 0.32 \\
$21-31 / 01$ & Jan 3 & 4.70 & 3.41 & 2.11 & 1.05 & 0.40 \\
$01-10 / 02$ & Feb 1 & 3.80 & 3.01 & 2.10 & 1.25 & 0.65 \\
$11-20 / 02$ & Feb 2 & 4.60 & 3.35 & 2.09 & 1.01 & 0.40 \\
$21-28 / 02$ & Feb 3 & 3.40 & 2.30 & 1.21 & 0.49 & 0.10 \\
$01-10 / 03$ & Mar 1 & 2.95 & 2.12 & 1.25 & 0.62 & 0.31 \\
$11-20 / 03$ & Mar 2 & 3.40 & 2.25 & 1.18 & 0.43 & 0.08 \\
$21-31 / 03$ & Mar 3 & 3.35 & 2.01 & 0.90 & 0.20 & 0.00 \\
$01-10 / 04$ & Apr 1 & 2.80 & 1.81 & 0.95 & 0.35 & 0.05 \\
$11-20 / 04$ & Apr 2 & 2.25 & 1.45 & 0.72 & 0.22 & 0.00 \\
$21-30 / 04$ & Apr 3 & 2.50 & 1.60 & 0.75 & 0.20 & 0.00 \\
$01-10 / 05$ & May 1 & 2.50 & 1.55 & 0.70 & 0.12 & 0.00 \\
$11-20 / 05$ & May 2 & 2.81 & 1.61 & 0.60 & 0.00 & 0.00 \\
$21-31 / 05$ & May 3 & 2.98 & 1.95 & 1.00 & 0.35 & 0.50 \\
$01-10 / 06$ & Jun 1 & 2.30 & 1.41 & 0.60 & 0.08 & 0.00 \\
$11-20 / 06$ & Jun 2 & 2.60 & 1.68 & 0.80 & 0.22 & 0.00 \\
$21-30 / 06$ & Jun 3 & 2.70 & 1.50 & 0.51 & 0.00 & 0.00 \\
$01-10 / 07$ & Jul 1 & 2.18 & 1.30 & 0.53 & 0.02 & 0.00 \\
$11-20 / 07$ & Jul 2 & 2.10 & 1.18 & 0.35 & 0.00 & 0.00 \\
$21-31 / 07$ & Jul 3 & 1.65 & 0.90 & 0.18 & 0.00 & 0.00 \\
& & & & & & continua
\end{tabular}


continuação

\begin{tabular}{lllllll}
$01-10 / 08$ & Aug 1 & 1.82 & 0.90 & 0.05 & 0.00 & 0.00 \\
$11-20 / 08$ & Aug 2 & 1.71 & 0.70 & 0.00 & 0.00 & 0.00 \\
$21-31 / 08$ & Aug 3 & 2.00 & 1.09 & 0.25 & 0.00 & 0.00 \\
$01-10 / 09$ & Sept 1 & 2.60 & 1.50 & 0.60 & 0.00 & 0.00 \\
$11-20 / 09$ & Sept 2 & 3.00 & 1.95 & 0.98 & 0.34 & 0.02 \\
$21-30 / 09$ & Sept 3 & 3.10 & 2.20 & 1.23 & 0.55 & 0.20 \\
$01-10 / 10$ & Oct 1 & 3.45 & 2.50 & 1.45 & 0.70 & 0.29 \\
$11-20 / 10$ & Oct 2 & 3.70 & 2.65 & 1.55 & 0.70 & 0.26 \\
$21-31 / 10$ & Oct 3 & 3.00 & 2.05 & 1.11 & 0.49 & 0.16 \\
$01-10 / 11$ & Nov 1 & 3.20 & 2.30 & 1.35 & 0.65 & 0.30 \\
$11-20 / 11$ & Nov 2 & 3.60 & 2.70 & 1.70 & 0.85 & 0.40 \\
$21-30 / 11$ & Nov 3 & 3.60 & 2.40 & 1.29 & 0.50 & 0.10 \\
$01-10 / 12$ & Dec 1 & 3.90 & 2.98 & 1.89 & 0.95 & 0.41 \\
$11-20 / 12$ & Dec 2 & 4.10 & 3.18 & 2.10 & 1.15 & 0.51 \\
$21-31 / 12$ & Dec 3 & 4.35 & 3.33 & 2.21 & 1.22 & 0.55 \\
\hline
\end{tabular}

Source: Elaboration of the authors.

For the first ten days of January, the probability of at least two days with rainfall greater than $10 \mathrm{~mm}$ was $50 \%$. This probability indicates that in two out of every four years, the number of days that will be unsuitable for outdoor work will exceed this value. The fewest days on which the rainfall level was greater than $10 \mathrm{~mm}$ were found during the second ten days of August. This period represents the ideal time to work under clear skies.
Table 4 presents the simple and conditional probabilities of favorable days (F) and unfavorable days (D) for work in the field in Londrina. The probabilities reflect a strong dependence on the condition of the previous day. Thus, a favorable day will be more probable if it is immediately preceded by a favorable day. In contrast, a favorable day will be less probable if it is immediately preceded by an unfavorable day. Analogous reasoning applies to the probability of an unfavorable day.

Table 4. Probabilities of favorable days for work in the field (P(F)), favorable days if the previous day was favorable $(\mathrm{P}(\mathrm{F} \mid \mathrm{F}))$, favorable days if the previous day was unfavorable $(\mathrm{P}(\mathrm{F} \mid \mathrm{D}))$, unfavorable days for work in the field $(\mathrm{P}(\mathrm{D}))$, unfavorable days if the previous day was favorable $(\mathrm{P}(\mathrm{D} \mid \mathrm{F}))$ and unfavorable days if the previous day was unfavorable $(\mathrm{P}(\mathrm{D} \mid \mathrm{D}))$. Londrina, $\mathrm{PR}$.

\begin{tabular}{ccccccc}
\hline 10-day periods & $\mathrm{P}(\mathrm{F})$ & $\mathrm{P}(\mathrm{F} \mid \mathrm{F})$ & $\mathrm{P}(\mathrm{F} \mid \mathrm{D})$ & $\mathrm{P}(\mathrm{D})$ & $\mathrm{P}(\mathrm{D} \mid \mathrm{F})$ & $\mathrm{P}(\mathrm{D} \mid \mathrm{D})$ \\
\hline Jan 1 & 0.68 & 0.79 & 0.48 & 0.32 & 0.21 & 0.52 \\
Jan 2 & 0.65 & 0.78 & 0.37 & 0.35 & 0.22 & 0.63 \\
Jan 3 & 0.66 & 0.81 & 0.43 & 0.34 & 0.19 & 0.57 \\
Feb 1 & 0.68 & 0.75 & 0.51 & 0.32 & 0.25 & 0.49 \\
Feb 2 & 0.64 & 0.76 & 0.40 & 0.36 & 0.24 & 0.60 \\
Feb 3 & 0.72 & 0.80 & 0.45 & 0.28 & 0.20 & 0.55 \\
Mar 1 & 0.77 & 0.85 & 0.48 & 0.23 & 0.15 & 0.52 \\
Mar 2 & 0.70 & 0.82 & 0.43 & 0.30 & 0.18 & 0.57 \\
Mar 3 & 0.77 & 0.86 & 0.47 & 0.23 & 0.14 & 0.53
\end{tabular}

continua 
continuação

\begin{tabular}{|c|c|c|c|c|c|c|}
\hline Apr 1 & 0.83 & 0.88 & 0.61 & 0.17 & 0.12 & 0.39 \\
\hline Apr 2 & 0.83 & 0.89 & 0.57 & 0.17 & 0.11 & 0.43 \\
\hline Apr 3 & 0.83 & 0.89 & 0.52 & 0.17 & 0.11 & 0.48 \\
\hline May 1 & 0.79 & 0.91 & 0.35 & 0.21 & 0.09 & 0.65 \\
\hline May 2 & 0.75 & 0.88 & 0.38 & 0.25 & 0.12 & 0.63 \\
\hline May 3 & 0.76 & 0.87 & 0.36 & 0.24 & 0.13 & 0.64 \\
\hline Jun 1 & 0.82 & 0.91 & 0.40 & 0.18 & 0.09 & 0.60 \\
\hline Jun 2 & 0.82 & 0.93 & 0.40 & 0.18 & 0.07 & 0.60 \\
\hline Jun 3 & 0.77 & 0.90 & 0.31 & 0.23 & 0.10 & 0.69 \\
\hline Jul 1 & 0.85 & 0.93 & 0.47 & 0.15 & 0.07 & 0.53 \\
\hline Jul 2 & 0.84 & 0.92 & 0.35 & 0.16 & 0.08 & 0.65 \\
\hline Jul 3 & 0.88 & 0.94 & 0.40 & 0.12 & 0.06 & 0.60 \\
\hline Aug 1 & 0.89 & 0.95 & 0.53 & 0.11 & 0.05 & 0.47 \\
\hline Aug 2 & 0.89 & 0.95 & 0.43 & 0.11 & 0.05 & 0.58 \\
\hline Aug 3 & 0.88 & 0.92 & 0.49 & 0.12 & 0.08 & 0.51 \\
\hline Sept 1 & 0.79 & 0.90 & 0.47 & 0.21 & 0.10 & 0.53 \\
\hline Sept 2 & 0.77 & 0.88 & 0.47 & 0.23 & 0.12 & 0.53 \\
\hline Sept 3 & 0.78 & 0.85 & 0.47 & 0.22 & 0.15 & 0.53 \\
\hline Oct 1 & 0.76 & 0.84 & 0.50 & 0.24 & 0.16 & 0.50 \\
\hline Oct 2 & 0.75 & 0.84 & 0.55 & 0.25 & 0.16 & 0.45 \\
\hline Oct 3 & 0.81 & 0.85 & 0.64 & 0.19 & 0.15 & 0.36 \\
\hline Nov 1 & 0.76 & 0.79 & 0.64 & 0.24 & 0.21 & 0.36 \\
\hline Nov 2 & 0.77 & 0.82 & 0.58 & 0.23 & 0.18 & 0.42 \\
\hline Nov 3 & 0.76 & 0.81 & 0.62 & 0.24 & 0.19 & 0.38 \\
\hline Dec 1 & 0.67 & 0.76 & 0.50 & 0.33 & 0.24 & 0.50 \\
\hline Dec 2 & 0.69 & 0.76 & 0.51 & 0.31 & 0.24 & 0.49 \\
\hline Dec 3 & 0.71 & 0.81 & 0.50 & 0.29 & 0.19 & 0.50 \\
\hline
\end{tabular}

Source: Elaboration of the authors.

The value of $\mathrm{P}(\mathrm{F})$ varied from $64 \%$ in the second ten days of February to $89 \%$ in the first and second ten-day periods in August. The average value of $\mathrm{P}(\mathrm{F})$ was $77 \%$, with a standard deviation of $7 \%$. The periods of the year most favorable to trafficability in the field were the month of April and the period from the first ten days of June to the third ten days of August, all with P(F) between 77-89\%.

The conditional probabilities $\mathrm{P}(\mathrm{F} \mid \mathrm{F})$ ranged from $75 \%$ in the first ten days of February to $95 \%$ in the first and second ten-day periods in August, with an average of $85 \%$ and a standard deviation of $6 \%$. These figures show that a favorable day is relatively probable immediately after a favorable day, resulting in two consecutive days favorable to the use of motorized equipment in the field. These conditional probabilities demonstrate the phenomenon of the persistence of the previous day's weather conditions (ASSIS et al., 1989). Based on this information, the optimum period for agricultural operations extends from the first ten days of June to the third ten days of August. The values of $\mathrm{P}(\mathrm{F} \mid \mathrm{F})$ were greater than $90 \%$ for these time intervals (Table 4 ). 
However, the conditional probabilities $\mathrm{P}(\mathrm{F} \mid \mathrm{D})$ varied between $31 \%$ in the third ten days of June to $64 \%$ in the third ten days of October and the first ten days of November. These values are relatively low because a favorable day is relatively less probable after an unfavorable day.

The most probable ten-day periods for the use of agricultural machinery in the field are determined by the local rainfall for the city. The knowledge of the most favorable periods is considered in conjunction with the moisture content of the soil to determine the times for sowing, harvesting and for the rational use of pesticides (ASSIS et al., 1989; PELOIA, MILAN, 2010).

The values shown in Table 4 can be used to identify the months associated with a higher probability of unfavorable days for the operation of machines in the field.

The $\mathrm{P}$ (D) values were complementary to the $\mathrm{P}$ (F) values, ranging from $11 \%$ in the first and second ten-day periods in August to $36 \%$ in the second ten days of February. The average value of P (D) was $23 \%$, with a standard deviation of $7 \%$. The least favorable period for field work includes the months of December and January and continues until the second ten days of February, with probability values between $29 \%$ and $36 \%$. This period coincides with the period during which the greatest precipitation occurred.

The occurrence of an unfavorable day immediately following an unfavorable day was relatively probable and demonstrated the dependence of adverse conditions for the use of machinery on the previous day's weather conditions, although the conditional probability was less than $\mathrm{P}(\mathrm{D} \mid \mathrm{F})$. The conditional probabilities $\mathrm{P}(\mathrm{D} \mid \mathrm{D})$ ranged between $36 \%$ in the third ten days of October and the first ten days of November to $69 \%$ in the third ten days of June. The second ten days of January, the month of May, the third ten days of June and the second ten days of July proved to be the most unfavorable as a result of the persistence of the previous day's weather conditions.

The values of $\mathrm{P}(\mathrm{D} \mid \mathrm{F})$ were substantially less than the values of $\mathrm{P}(\mathrm{F} \mid \mathrm{D})$, ranging from $5 \%$ in the first and second ten-day periods in August to $25 \%$ in the first ten days of February. The highest values were concentrated in December, January and February (19-25\%), with lower values during July and August (5-8\%). The probability of an unfavorable day if the previous day is favorable is much smaller than the probability of a favorable day if the previous day is unfavorable.

The results of this study are consistent with the findings of Assis et al. (1989), who applied the same methodology to obtain the probabilities, on a weekly basis, for days on which tractors could be operated between August 31 and May 2 in Uberaba, MG. The authors concluded that the probable number of favorable days, at a probability level of 0.93 , was 33 days throughout the observation period. At a probability level of 0.80 , zero to four favorable days are expected to occur.

Similarly, Fernandes, Souza and Vitoria (2000) determined the number of potentially useful days for working with machines in Forest Ganhães, MG, Brazil. A total of 170 working days per year occurred between March and September, with the best period from June to August. The authors concluded that the months from October to February provided the smallest number of working days due to the distribution of rainfall during the year and the water-holding capacity of the soil in the region.

\section{Conclusions}

The negative binomial distribution function was adequate to adjust the monthly data and the tenday periods of the year in which rainfall equals or exceeds $10 \mathrm{~mm}$ in Londrina, PR.

The most favorable period for outdoor work in Londrina is from April to September, with an optimum between the third ten days of July and the first ten days of September. The period that would 
not be recommended is the period of concentrated rainfall, from October to February.

The probability of a favorable day for work with farm machinery is highest in April and from the first ten days of June to the third ten days of August. The odds of two consecutive favorable days for field work with machinery are best between June and August.

The probabilities presented enable the determination of the needs for machinery to be used for the implementation of mechanized agricultural practices.

\section{Acknowledgments}

We thank CAPES for the $\mathrm{PhD}$ scholarship granted to the first author.

\section{References}

ARAUJO-JUNIOR, C. F.; DIAS JUNIOR, M. de S.; GUIMARÃES, P. T. G.; ALCÂNTARA, E. N. Capacidade de suporte de carga e umidade crítica de um Latossolo induzida por diferentes manejos. Revista Brasileira de Ciência do Solo, Viçosa, MG, v. 35, n. 1, p. 115-131, fev. 2011.

ASSIS, F. N.; ARRUDA, H. V.; PEREIRA, A. R. Aplicações de estatística à climatologia: teoria e prática. Pelotas: Universidade Federal de Pelotas, Universitária, 1996. $161 \mathrm{p}$.

ASSIS, S. V. de; SEDIYAMA, G. C.; VIANELLO, R. L.; MARTYN, P. J. Probabilidade de ocorrência de dias trabalháveis com tratores agrícolas em Uberaba, Minas Gerais. Revista Ceres, Viçosa, MG, v. 36, n. 206, p. 299316, jul./ago. 1989.

BAZZANO, M. G. P.; ELTZ, F. L. F.; CASSOL, E. A. Erosividade, coeficiente de chuva, padrões e período de retorno das chuvas de Quaraí, RS. Revista Brasileira de Ciência do Solo, Viçosa, MG, v. 31, n. 5, p. 1205-1217, out. 2007.

BERNARDO, S.; MONTOVANI, E. C.; SOARES, A. A. Manual de irrigação. Viçosa: UFV, 2005. 611 p.

BLAIN, G. C.; BRUNINI, O. Caracterização do regime de evapotranspiração real, em escala decendial, no Estado de São Paulo. Revista Brasileira de Meteorologia, São José dos Campos, v. 22, n. 1, p. 75-82, 2007.
BURIOL, G. A.; ESTEFANEL, V.; GRAVE, R. A.; DIDONET, I. A.; STEINMEIZ, S. Probabilidade de ocorrência de temperaturas mínimas do ar prejudiciais à fecundação das flores de arroz na região da depressão central, Estado do Rio Grande do Sul, Brasil. Ciência Rural, Santa Maria, v. 28, n. 1, p. 1-9, 1998.

CASTRO NETO, P. Desenvolvimento e avaliação de equipamentos e metodologia para determinação de parâmetros físicos do solo relacionados a dias trabalháveis com máquinas agrícolas. 2001. Tese (Doutorado em Energia na Agricultura) - Faculdade de Ciências Agronômicas. Universidade Estadual Paulista, Botucatu.

EMPRESA BRASILEIRA DE PESQUISA AGROPECUÁRIA - EMBRAPA. Sistema brasileiro de classificação de solo. 2. ed. Rio de Janeiro: Embrapa Solos. Brasília: Sistemas de Informações, 2006. 306 p.

FARIA, R. T.; CARAMORI, P. H. Caracterização físicohídrica de um Latossolo Roxo distrófico do município de Londrina, PR. Pesquisa Agropecuária Brasileira, Brasília, v. 21, n. 12, p. 1303-1311, 1986.

FERNANDES, H. C.; SOUZA, A. P. de; VITORIA, E. L. da. Determinação do número de dias potencialmente úteis para o trabalho com máquinas florestais. Revista Árvore, Viçosa, v. 24, n. 3, p. 269-274, 2000.

MASSIGNAM, A. M.; DITTRICH, R. C. Estimativa do número médio e da probabilidade mensal de ocorrência de geadas para o Estado de Santa Catarina. Revista Brasileira de Agrometeorologia, Santa Maria, v. 6, n. 2, p. 213-220, 1998.

MURTA, R. M.; TEODORO, S. M.; BONOMO, P.; CHAVES, M. A. Precipitação pluvial mensal em níveis de probabilidade pela distribuição gama para duas localidades do sudoeste da Bahia. Ciência $e$ Agrotecnologia, Lavras, v. 29, n. 5, p. 988-994, 2005.

NAGAOKA, A. K.; LANÇAS, K. P.; CASTRO NETO, P.; LOPES, A.; GUERRA, S. P. S. Resistência do solo à penetração, após o tráfego com dois tipos de pneus utilizando-se um equipamento para ensaio dinâmico. Revista Brasileira de Engenharia Agrícola e Ambiental, Campina Grande, v. 7, n. 2, p. 387-393, maio/ago. 2003.

PELOIA, P. R.; MILAN, M. Proposta de um sistema de medição de desempenho aplicado à mecanização agrícola. Engenharia Agrícola, Jaboticabal, v. 30, n. 4, p. 681-691, jul./ago. 2010.

RICARDO, H. de S.; CATALANI, G. Manual prático de escavação: terraplenagem e escavação de rocha. 2. ed. São Paulo: Pini, 1990. 656 p. 
SALVADOR, N.; MION, R. L.; BENEZ, S. H.; VILIOTTI, C. A. Estudo da demanda energética e desagregação do solo em diferentes sequências operacionais de preparo periódico. Revista Ciência Agronômica, Fortaleza, v. 41, n. 2, p. 231-236, abr./jun. 2010.

SELIRIO, I. S.; BROWN, D. M. Estimation of spring workdays from climatological records. Canadian Agricultural Engineering, Ottawa, v. 14, n. 2, p. 79-81, dez. 1972.
SILVA, J. C. da; HELDWEIN, A. B.; MARTINS, F. B.; TRENTIN, G.; GRIMM, E. L. Análise de distribuição de chuva para Santa Maria, RS. Revista Brasileira de Engenharia Agrícola e Ambiental, Campina Grande, v. 11, n. 1, p. 67-72, 2007.

THORNTHWAITE, C. W.; MATHER, J. R. The water balance. Climatology, New Jersey, v. 8, n. 1, p. 1-40, 1955. 